\title{
Dönüşümsel Liderliğin Sosyal Sermayeye Etkisinde Lider-Üye Etkileşiminin Aracılık Rolü (The Mediating Role of Leader-Member Exchange in the Effect of Transformational Leadership on Social Capital)
}

\author{
Metin SÖYLEMEZ iDa Metehan TOLON iDb \\ aMuş Alparslan Üniversitesi, İktisadi ve İdari Bilimler Fakültesi, İşleme Bölümü, Muş, Türkiye. met.soylemez@gmail.com \\ bAnkara Hacı Bayram Veli Üniversitesi, İktisadi ve İdari Bilimler Fakültesi, İşleme Bölümü, Ankara, Türkiye. metehan@gazi.edu.tr
}

\begin{tabular}{|c|c|}
\hline MAKALE BİLGİSİ & ÖZET \\
\hline $\begin{array}{l}\text { Anahtar Kelimeler: } \\
\text { Dönüşümsel Liderlik }\end{array}$ & $\begin{array}{l}\text { Amaç - Dönüşümsel liderliğin, örgütsel bir kaynak olarak sosyal sermayenin biçimlendiril- } \\
\text { mesindeki etkisi ve bu etkide lider-üye etkileşiminin aracılık rolü, sosyal değişim teorisine } \\
\text { dayanarak ortaya konulması amaçlanmıştır. }\end{array}$ \\
\hline Lider-Üye Etkileşimi & $\begin{array}{l}\text { Yöntem - Anket yöntemi ile saha çalışması sonucu elde edilen veriler hipotez testleri için } \\
\text { kullanılmıştır. Toplamda } 504 \text { katılımcıdan elde edilen verilerin analizinde, doğrusal regresyon } \\
\text { ve bootstrap ile aracılık testleri kullanılmıştır. }\end{array}$ \\
\hline $\begin{array}{l}\text { Gönderme Tarihi } 2 \text { Ocak } 2019 \\
\text { Revizyon Tarihi } 5 \text { Mart } 2019\end{array}$ & $\begin{array}{l}\text { Bulgular - Elde edilen bulgularla, kurgulanan hipotezler desteklenerek, dönüşümsel liderliğin } \\
\text { sosyal sermayeyi etkilediği ve dönüşümsel liderliğin sosyal sermayeyi etkilemesinde, lider-üye } \\
\text { etkileşiminin kısmi aracı rolü oynadığı tespit edilmiștir. }\end{array}$ \\
\hline $\begin{array}{l}\text { Makale Kategorisi: } \\
\text { Araştırma Makalesi }\end{array}$ & $\begin{array}{l}\text { Tartışma - Bu çalışma, dönüşümsel liderliğin ilişkisel yönünü vurgulayarak, sosyal sermaye ve } \\
\text { lider-üye etkileşimi gibi önemli kavramları etkileyen alternatif bir güç olduğunu } \\
\text { savunmaktadır. Takipçiler, dönüşümsel liderleri, güvenilir ve destekleyici olarak algılar. Bu } \\
\text { algı, takipçilerin örgüte daha iyi uyum sağlamalarını sağlayan, psikolojik rahatlık ve güvenlik } \\
\text { duygusunu yaratır. Böylece takipçiler, paylaşılan vizyon çerçevesinde, diğer takipçiler ile } \\
\text { uyumlu bir sosyal varlık haline gelerek, lider tarafından belirlenen ortak amaçlara ulaşmak için } \\
\text { işbirliği içinde çalışr. Bu uyum ve paylaşılan liderlik etrafında işbirliği içinde çalışma, bilgi gibi } \\
\text { olumlu sosyal değişimlere sebep olarak, güçlü bir sosyal sermaye yapısına yol açar. }\end{array}$ \\
\hline
\end{tabular}

\begin{tabular}{ll}
\hline ARTICLE INFO & ABSTRACT \\
\hline $\begin{array}{l}\text { Keywords: } \\
\text { Transformational Leadership }\end{array}$ & $\begin{array}{l}\text { Purpose - The effect of transformational leadership on the shaping of social capital as an } \\
\text { organizational resource and the mediating role of the leader-member exchange in this effect is } \\
\text { presented based on the theory of social change. }\end{array}$ \\
Leader Member Exchange & $\begin{array}{l}\text { Design/methodology/approach - The field study data obtained by survey method were used } \\
\text { for hypothesis testing. Linear regression and mediation with bootstrap tests are used to analyse } \\
\text { the data obtained from 504 participants. }\end{array}$ \\
Received 2 January 2019 & $\begin{array}{l}\text { Findings - The results show that transformational leadership affects social capital, and leader- } \\
\text { member exchange plays a partial mediator role between transformational leadership and social } \\
\text { Revised 5 March 2019 }\end{array}$ \\
Accepted 10 March 2019 & $\begin{array}{l}\text { Discussion - By emphasizing the relational aspect of transformational leadership, this study } \\
\text { argues that it is an alternative force that influences important concepts such as social capital and } \\
\text { leader-member exchange. Followers perceive transformational leaders as reliable and } \\
\text { supportive. This perception creates a sense of psychological comfort and security that enables } \\
\text { the followers to better adapt to the organization. Thus, in the framework of shared vision, } \\
\text { followers work in cooperation with other followers in order to reach the common goals } \\
\text { Research Article }\end{array}$ \\
$\begin{array}{l}\text { determined by the leader. This harmony, and working in collaboration around shared } \\
\text { leadership lead to a strong social capital structure by causing positive social changes such as } \\
\text { knowledge. }\end{array}$
\end{tabular}




\section{Giriş}

Örgütlerin, küreselleşme dinamikleri çerçevesinde büyüyüp gelişmesi ile kaliteli insan kaynağına olan ihtiyaç, hem rekabet şartlarına uyumu hem de sürdürebilir rekabet üstünlügünü korumayı etkilemektedir. Örgütler, bu ihtiyacın giderilebilmesi amacıyla çevre şartlarının hızla değiştiği günümüz dünyasında, insan kaynakları uygulamalarını daha etkili hale getirmek için insan sermayelerini geliştirmek zorundadır. Çünkü insan kaynakları yönetimi uygulamaları sürdürülebilir rekabet üstünlüğü sağlama kaynağı olarak, birbiriyle ilişkili, içsel tutarlılığa sahip, sinerji sağlayan, taklit edilemeyen, değerler zinciridir(Boxall, 1996; Kaufman, 2015). Bu bağlamda, insan kaynakları yönetiminin temel yapı taşı olan sosyal sermaye, yüksek derecede adanmış ve yetenekli bir işgücünün stratejik gelişimi yoluyla rekabet üstünlüğü elde etmek için insanları yöneltmeyle ilgili olan farklı bir yaklaşımdır(Huselid, 1995). Ayrıca bu argümanla tutarlı olarak, çalışanların, beceri kazanma ve gelişimlerinin, insan kaynaklarını kritik bir fonksiyonu olan, sosyal sermayenin geliştirilmesi yoluyla desteklenebileceğini belirtilmektedir(Ployhart, 2006; Youndt vd., 1996).

Sosyal sermayenin, örgütsel bir olgu olarak incelenmesi giderek daha fazla ilgi görmektedir. Sosyal sermaye, örgüt üyelerinin, ortak amaç yönelimi ve aralarındaki paylaşılan güvenin sonucu olarak ortaya çıkan, örgüt içi sosyal ilişkilerin özelliği olarak tanımlanabilir. Aynı zamanda sosyal sermaye, örgütün dış kaynaklara erişimini sağlayan (Hitt vd., 2002) ve içsel koordinasyonun kolaylaştırılmasına yardımcı olan, önemli bir kaynaktır(Sirmon vd., 2007). Bunlara ek olarak, örgüt içi sosyal ilişkilerin sonucu olması sebebiyle en dayanıklı örgütsel kaynaklardan biri olan sosyal sermaye, işlem maliyetlerini azaltması, bilgi akışını kolaylaştırması ve bilginin yaratılmasını olanaklı hale getirmesi yoluyla, bir örgütün etkililiğini şekillendirmede çok önemli bir rol oynamaktadır(Balkundi ve Kilduff, 2006; Lin, 2002; Nahapiet ve Ghoshal, 1998; Oh vd., 2004). Kaynak bakış açısı ile sosyal sermaye, var olduğu örgütün kendisiyle özdeşleştiğinden, tedarik edilemez veya bir başka sosyal sistemden örgüt bünyesine aktarılamaz(Nahapiet ve Ghoshal, 1998). Örgütlerin sürdürülebilirliklerinin sağlanması ve büyümeleri için bu kadar önemli bir olgu olan sosyal sermaye, diğer örgütsel konulara nispeten yeterine araştırılmamış, keşfedilmeye açık bir kavram olarak ortaya çıkmaktadır(Adler ve Kwon, 2002; Bolino vd., 2002; Hodson, 2005; Phelps vd., 2012; Whipple vd., 2015). Bu çerçevede liderliğin, sosyal sermayeyi örgüt için faydalı bir çıktıya dönüştürmede ki rolü çalışmasının odak noktasını oluşturmaktadır. Bazı araştırmacılar yönetimsel davranışların sosyal sermayenin biçimlenmesindeki etkisini ortaya koymuş olmalarına rağmen(Johnson vd., 2013; Li vd., 2014), liderliğin sosyal sermayenin biçimlendirilmesindeki etkisi ve liderliğin sosyal sermaye üzerindeki etkisin altında yatan mekanizmalar tam manasıyla ortaya koyulamamıştır.

Liderlik, örgütler için sürdürülebilir rekabet üstünlüğü elde etmek için güçlü bir katalizör kaynaktır(Grant, 1991). Günümüzde liderlik, basit bir lider takipçi arasındaki ilişkiden öte, insan kaynağının sahip olduğu potansiyelin, hem bireysel hem de örgütsel düzeyde en fazla faydayı yaratabilecek çıktıya dönüştüğü, takipçilerin duygusal yönlerine daha fazla önem veren, ilişki odaklı bir anlayış olarak, rekabet üstünlügünün sürdürülebilirliğini sağlama aracı olarak görülmektedir. Bu ilişki odaklı yeni liderlik paradigması çerçevesinde kavramsallaştırılan idealize edilmiş etki, ilham verici motivasyon, entelektüel teşvik ve bireysel ilgi eksenli(Bass, 1990) dönüşümsel liderlik, bu çalışmanın odak noktasıdır. Dönüşümsel liderlik örgütsel bağlllık, bireysel performans(Banks vd., 2016; Van Knippenberg ve Sitkin, 2013) yaratıcılık, işten ayrılma niyeti ve ekstra rol davranışları(Herman ve Chiu, 2014; To vd., 2015) dâhil olmak üzere çok çeşitli örgütsel açıdan önemli sonuçları olumlu yönde etkilemektedir.

Dönüşümsel liderler stratejik bir vizyon yaratarak, bu vizyonu rol model olarak kendi davranış biçiminde sürekli uygulayarak, takipçilerine aktarır ve örgütsel düzeyde bu vizyona bağlllık geliştirir(Avolio ve Bass, 1993). Böylece, dönüşümsel liderlik takipçilerin arasında daha fazla uyumun, güvenin ve performansın oluştuğu bir örgütsel iklime doğru, etkin bir değişim ortaya çıkarmaktadır. Kadrolama, eğitim, performans değerlendirme ve ücretlendirme sistemleri gibi olumlu insan kaynakları yönetimi uygulamaları, liderlerin takipçilerine yönelik bireysel ilgilerini onlara hissettirdikleri yollardır. Dönüşümsel liderler, takipçilerinin arzu ve isteklerini dikkatle dinleyerek ve bir mentor gibi hareket ederek takipçilerinin ihtiyaçlarına ve gelişimlerine özel önem atfederler. Bu sayede, sosyal sermaye, inşa edilerek, çalışanların ve takipçilerin, örgüt için daha etkili bir insan kaynağına dönüşmelerini sağlarlar(Zhu vd., 2005). Dönüşümsel liderlik teorisi, dönüşümcü liderlerin, takipçilerin kendi öz çıkarlarını ötesine geçerek örgüt yararına, takipçiler tarafından paylaşılan ortak bir vizyon geliştirerek, takipçilerin bu vizyona bağlılığını oluşturma ve böylece 
sosyal sermayenin gelişimine katkıda bulunmalarını etkileyebileceğini savunmaktadır(Bass, 1985). Başka bir ifadeyle, dönüşümcü liderler, takipçilerine ortak bir vizyon, özdeşleşme duygusu ve amaç uyumu sağlayarak, sosyal sermayeyi oluşturan önemli araçları istikrarlı hale getirirler(Bass ve Riggio, 2006).

Diğer taraftan, bu çalışmanın amaçlarından biri de, lidere, takipçiye ve aralarında ki ilişkiye ve ilişkinin kalitesine odaklanan, ilişki tabanlı bir yaklaşım olan lider-üye etkileşiminin(Graen ve Uhl-Bien, 1995) dönüşümsel liderliğin sosyal sermayeyi güçlendirmesinde nasıl bir kolaylaştırıcı etki yaptığının ortaya çıkarılmasıdır. Lider-üye etkileşim teorisinin ana amacı, lider ve takipçi arasında etkili bir iletişimin sonucu olarak artan etkililiğin oluşması ve kazanımlara erişim sağlanmasıdır(Gerstner ve Day, 1997). Bu çerçevede, dönüşümsel liderler örgüt çıkarlarını takipçilerin kişisel çıkarlarının önüne geçirerek oluşturduğu paylaşılan vizyonu, lider-üye etkileşim sonucu oluşan kaliteli ilişkiler çerçevesinde geliştirerek, sosyal sermayeyi güçlendirirler.

Sosyal sermaye literatüründe örgütsel sosyal sermaye henüz yeterince araştırılmamış, keşfedilmeye açık bir alan olarak kabul edilmektedir(Adler ve Kwon, 2002; Bolino vd., 2002; Hodson, 2005). Bu literatür boşluğunu, kaynak bakış açısıyla, dönüşümsel liderliğin sosyal sermayeyi örgütler için rekabet üstü olmayı sağlayan bir kaynak olarak nasıl beslediğini, ortaya koyarak doldurmak, bu çalışmanın amaçlarından biridir. Diğer taraftan, dönüşümsel liderliğin sosyal sermayeyi güçlendirmesinde, dönüşümsel liderlik, ilişki tabanlı bir model olarak, lider ve takipçi arasında ki basit bir sosyal değişimin ötesine geçmektedir(Balkundi ve Kilduff, 2006). Sosyal değişim teorisi ve sosyal ağ yaklaşımı çerçevesinde, örgütsel aktörlerin arasındaki etkileşim, sadece aktörlerin özellikleri ve davranış stilleri kapsamında açıklanmaktan öte, aralarındaki sosyal değişimin sonucu ve karşlıklı yükümlülüklerin yerine getirildiği bilişsel bir süreç olarak, sosyal sermayenin güçlendirildiği bir yapıdır(Chun vd., 2016; Ibarra vd., 2005). Bu kapsamda, dönüşümsel liderliğin sosyal sermayeyi etkilemesinde, lider-üye etkileşimi aracılık etkisinin ortaya konulması, çalışmanın literatüre bir diğer önemli katkısıdr.

\section{Literatür Taraması}

\subsection{Dönüşümsel Liderlik}

Dönüşümsel liderlik, liderin karizmatik ve ilham veren yönlerine odaklanan, yeni liderlik paradigmasının bir parçası olarak kavramsallaştırılmıştır(Northouse, 2018: 161). Dönüşümsel liderliğin teorik özü, insanları değiştirip dönüştürmesidir(Avolio vd., 2004; Bass ve Riggio, 2006; Northouse, 2018). Dönüşümsel liderlik, liderin etik anlayışı, değerleri ve uzun dönem hedefleri ile ilgilidir(Bass, 1985; Bass ve Riggio, 2006; Brown ve Treviño, 2006). Diğer liderlik yaklaşımları ile karşılaştırıldığında, liderlik stili, takipçilerin motivasyon ve duygularına daha fazla önem verir. Dönüşümsel liderliğin ana amacı, takipçilerin güdü ve ihtiyaçlarını tatmin ederek, onların en üstün performanslarına ulaşmaları için gereken fırsatı vermektir. Dönüşümsel liderler, karizma ve ilham verme faktörlerini etkileme sürecine dahil ederek, takipçilerinin beklenenden öte bir performans göstermelerini sağlarlar.

Bass (1985) dönüşümsel liderlik davranışlarının kullanılarak, takipçilerin beklenenden daha fazla motive edileceğini belirtmektedir. Bu motivasyon, takipçilerin idealize edilmiş hedeflerin önemi hakkında bilinçlendirilmesini, örgütün çıkarlarını kendi çıkarlarından daha üstün görmelerini ve kendilerini gerçekleştirme ihtiyacını arzulamaları ile sağlanmaktadır(Bass, 1985: 20). Bass (1985)'a göre fizyolojik ve diğer alt düzey ihtiyaçlar tatmin edildikten sonra kendini gerçekleştirme ihtiyacı uyarıldığında, bireyler normalde göstereceklerinden daha fazla performans göstererek, öz çıkarlarının kendilerini yozlaştırmasını engellerler.

Yukarıda belirtildiği gibi dönüşümsel liderlik bireylerin değiştirildiği ve dönüştürüldüğü bir süreçtir. Dönüşümsel liderler bu değişim ve dönüşümü gerçekleştirirken, dönüşümsel liderliğin boyutlarını oluşturan: İdealize Edilmiş Etki, İlham Verici Motivasyon, Entelektüel Teşvik, Bireysel İlgi olmak üzere 4 farklı davranış biçimi gösterirler(Bass ve Riggio, 2006). Bu davranışlar, takipçilerin gelişimsel süreçlerini desteklemek amacıyla dönüşümsel liderlere, takipçilerinin motivasyonlarının arttırılmasında ve duygularına karşlık verilmesinde yardımcı olur(Avolio vd., 1999).

İdealize Edilmiş Etki: Dönüşümsel liderler, takipçilerine çekici bir rol model olarak davranırlar. İdealize edilmiş etki boyutu, dönüşümsel liderliğin duygusal bir bileşenedir ve liderin karizmasını ve diğer rol 
modeli olma vasıflarını sergilemesi olarak tanımlanabilir(Bass, 1985). Ayrıca idealize edilmiş etki, dönüşümsel liderliği, diğer liderlik yaklaşımlarından farklılaştıran faktör olarak tanımlanmaktadır(Bass ve Riggio, 2006; Judge vd., 2002).

İlham Verici Motivasyon: Dönüşümsel liderler, takipçilerini motive ederek ve ilham vererek, onların daha yüksek performans seviyesine ulaşmasını sağlar(Liu vd., 2010). Dönüşümsel liderler, berrak ve çekici bir gelecek vizyonu ortaya koyarak, takipçilerin bu vizyona ulaşarak mükemmel sonuçlara ulaşacakları konusunda onlara ilham verir. Takipçiler örgütün çıkarlarını bireysel çıkarlarından daha önemli görürler, çünkü dönüşümsel liderler yaptıkları faaliyetin amacının ve anlamının önemini kutsallaştırarak, daha öncelikli hale getirir(Bass ve Riggio, 2006). İlham verici motivasyonla, takipçiler daha yüksek hedefleri başarmaya sevk edilerek, canlandırılır ve motive edilir.

Entelektüel Teşvik: Dönüşümsel liderler takipçilerinin yaratıcılığını ve entelektüel çabalarını teşvik ederler. Dönüşümsel lider takipçilerinin varsayım ve inançlarını hesaba katarak, inovatif fikir ve çözümlerin ortaya çıacağı bir iklim oluşturur. Takipçiler problemlere farklı açılardan bakarak yeni yaklaşımları denemeleri noktasında desteklenirler. Dönüşümsel liderler, yeni fikirleri ve yaratıcıllı̆ı hoş karşılar. Ayrıca dönüşümsel liderler, takipçilerinin öneri ve fikirlerine göz önüne alarak onlara önem verir. Hatalar veya liderin fikrinden farklı fikirler, alenen ve olumsuz olarak eleştirilmez(Bass ve Riggio, 2006).

Bireysel İlgi: Dönüşümsel liderler takipçilerinin ihtiyaçları ile ilgilenerek, onların gelişimlerine özel bir önem verir ve destekler. Bu liderlik davranış biçiminde liderler, takipçilerinin ihtiyaç ve kaygıları kapsamında onlara danışmanlık yapar. Her bir takipçisine özgü problem ve zorlukla ilgili olarak, bireysel problem ve zorluklara uygun özel ilgi gösterir. Araştırmacılar dönüşümsel liderliğin boyutlarından olan bireysel ilginin, dönüşümsel liderlere, takipçilerinin uzun dönemli gelişmesinde çok önemli olduğunu belirtmektedirler(Bass ve Riggio, 2006; Shamir vd., 1993). Çünkü dönüşümsel liderlerin, takipçilerinin problemleriyle başa çıkmada onlara verdiği destek ve ilgi, takipçilerin zorlukların üstesinden gelmelerini ve tüm potansiyellerinin ortaya çıkması için gerekli gelişimi sağlar(Bass, 1990; Judge ve Bono, 2000; Piccolo ve Colquitt, 2006).

\subsection{Lider-Üye Etkileşim Teorisi}

Lider-üye etkileşim teorisi, lidere, takipçiye ve aralarında ki ilişkiye ve ilişkinin kalitesine odaklanan ilişki tabanlı bir yaklaşımdır(Gerstner ve Day, 1997; Graen vd., 1982; Graen ve Uhl-Bien, 1995; Liden vd., 1997). Graen ve Uhl-Bien (1995)'e göre LÜE teorisinin ana teması, lider ve takipçi arasında etkili bir iletişimin sonucu olarak artan etkililiğin oluşması ve kazanımlara erişim sağlanmasıdır(Gerstner ve Day, 1997). Teori, lider ve takipçileri arasında etkili bir ikili ilişki liderliğinin (Liden vd., 1997; Uhl-Bien vd., 2000) sonucu olarak etkili liderliğin kaynağını(Graen ve Uhl-Bien, 1991; Graen ve Uhl-Bien, 1995) ve bunun yanında örgütsel çıtılara olan faydasını konu edinmektedir(Gerstner ve Day, 1997).

LÜE teorisine göre, lider ve takipçileri arasındaki ikili ilişkilerin kalitesi bireysel, grupsal ve örgütsel düzeyde çıktıları öngörür. Bu ikili ilişkinin açıklanışı olarak, LÜE teorisi, rol teorisine dayanmakla beraber(Graen ve Scandura, 1987) sonrasında sosyal değişim teorisi ekseninde geliştirilmiştir(Erdogan vd., 2004; Liao vd., 2010). Rol teorisine(Katz ve Kahn, 1978) göre, örgütün faaliyetleri lider ve takipçilerden beklenen roller çerçevesinde yerine getirilir. Lider, takipçisinin rolünün bir parçası olarak, ondan durumla ve yapılan faaliyetle ilgili davranışlar, standartlar ve olumlu bir tutum bekler(Cropanzano ve Mitchell, 2005). Bu beklenti, takipçilerin davranışlarını ve rol performansı için gerekli olan motivasyonlarını etkiler(Biddle, 1986). Takipçilerden beklenen bu roller, takipçiler tarafından kabul, ret edilebilir veya yeniden müzakere edilebilir(Tsui, 1984). Bu noktada, teorinin özü olarak, lider, takipçilerin her biriyle aynı ilişkiyi geliştirmez ve ilişkinin kalitesi takipçiye göre farklılaşmaktadır(Graen ve Uhl-Bien, 1995). Bu farklılaşma, takipçilerin, grup içi ve grup dışı olarak sınıflandırılmasına sebep olmaktadır. Sonrasında, LÜE teorisi, sosyal değişim teorisiyle(Blau, 1964) ilişkilendirilerek, lider ve takipçi arasındaki ilişkiler yüksek ve düşük kalite ilişki bağlamında sınıflandırılmıştır. Sosyal değişim tabanlı, yüksek kaliteli ilişki, lider ve takipçi arasında karşılıklı güven, adanmışlık, saygı ve kişilerarası bağlılık oluştururken, düşük kaliteli ilişkiler, ekonomik/somut şeylerin değişimi olarak biçimsel, rol tanımlı etkileşim çerçevesinde yukarıdan aşağıya doğru bir etki ve yüksek güç mesafesi meydana getirir(Harris vd., 2014; Sparrowe ve Liden, 1997). 
Sosyal değişim teorisinde ana odak; birey kendine sağlanacak, beklediği yararın karşılığı olarak eşit düzeyde başkalarına yarar sağlayacaktır(Gouldner, 1960). Sosyal değişim, biçimsel olmayan bir ilişkinin sonucu olarak, bireylerin birbirine karşı oluşan güven ve yükümlülük duyguları sonucu oluşur. Böylece sosyal değişim ilişkisi, bireyler arasında karşılıklı bir yükümlülük ve diğerinin gereksinimlerine adanmışlıktır(Cropanzano ve Mitchell, 2005; Henderson vd., 2008). Karşılıklılık normu sosyal değişim ilişkilerinin temel ilkesidir. Karşılıklılık normu gereği takipçi maddi veya manevi destek aldığı sürece, liderin değerleri ve istekleri çerçevesinde daha fazla performans ve örgütsel vatandaşlık davranışı gösterecektir. Karşılıklılık normu, üstü kapalı bir pazarlık olmayıp(Molm, 1994), etkileşim, liderin davranışlarına bağlıdır. Liderin davranışlarına bağlı olması riski azaltarak dayanışmayı destekler ve yüksek kaliteli ilişkilerin ortaya çımasını sağlar(Cropanzano ve Mitchell, 2005).

\subsection{Sosyal Sermaye}

Sosyal sermaye kavramı sosyal bilimlerin birçok alanında araştırmaya konu olan ekonomik ve kurumsal performansın açıklayıcı bir faktörü olarak yer almaktadır. Bunun yanında sosyal sermaye kavramı tüm sosyal bilimlerin ortak bir kavramına dönüşmektedir(Paldam, 2000). Sosyal sermaye, farklı analiz düzeylerinden tanımlanmaktadır. Örneğin Bourdieu (1986)' nun sosyal sermaye bakış açısı, bireyselden öte toplumsal olarak kavramsallaştırarak, belli grupların sosyal sermayeyi ortak bir varlık olarak nasıl geliştirip sürdürülebileceğini ve bu ortak varlığın toplumun üyelerine nasıl yararlı olabileceğini açılamaya çalışmaktadır. Diğer taraftan, bireysel seviyede mikro bakış açısıyla sosyal sermaye; bireylerin sosyal ilişkilere yatırım yaparak, bu ilişkilerin sonuçlarından nasıl yararlanabileceğini sorgulamaktadır. Bu seviyede, bireyin sosyal ağ bağlantılarında veya sosyal yapıda gizli saklı ulaşılabilir kaynaklar bireye fayda sağlamaktadır(Lin, 2002). Örneğin, Lin (1982)' e göre bireyler, kişisel kaynaklar ve sosyal kaynaklar olmak üzere iki çeşit kaynağı bireysel ilerlemesinde kullanır. Kişisel kaynaklar bireyin diploması, dereceleri gibi kişiye has kaynaklar iken, sosyal kaynaklar ise bireyin sosyal ilişkilerinin yaygınlık ve çeşitlilik seviyesidir. Bunun yanında Flap (1995)' e göre sosyal sermaye; bireyin ilişkide bulunduğu ve birey tarafında istendiği takdirde yardıma hazır olmayı yükümlülük olarak hisseden kişi sayısına, yardıma hazır olan kişilerle olan ilişkinin gücüne ve bu kişilerin kaynaklarına bağlıdır. Bir diğer mikro bakış açısı, ağ bağlantılarının kesişme noktasında ki bireylerin daha fazla bilgiye sahip olacağını atıfla sosyal sermayeyi açılanmaktadır(Burt, 1997).

Bireysel ve toplumsal bakış açılarının yanında, diğer bir bakış açısı olan grup veya örgüt seviyesinde sosyal sermayede, analiz birimi olarak odak noktası sosyal gruplardır. Analiz birimi içsel sosyal sermayenin olarak örgütün kendisi olabileceği gibi, dışsal sosyal sermaye olarak paydaşlar veya ilişkide bulunulan diğer sosyal gruplar olabilir. İçsel sosyal sermaye grup veya örgüt üyelerinin ilişkilerinin sonucu iken(Akram vd., 2016; Huber, 2009), dışsal sosyal sermaye ise örgütün dış çevresinde bulunan birey veya gruplarla oluşan ilişkilerin sonucudur(Wu, 2008; Zahra, 2010). Grup veya örgüt düzeyinde sosyal sermaye bireysel bir varlık olmaktan öte karşılıklı güven ve yükümlülüğün sonucu olarak ortak bir varlıktır(Bhandari ve Yasunobu, 2009). Grup, paylaşılan deneyimler, ait olma hissi, ortak sebep birlikteliği ve ortak hareket mekanizması olarak, örgüt veya gruptaki paylaşılan normlar ve inançlar, bireyin davranışlarını etkilemektedir. Ayrıca grup ve örgüt düzeyinde var olan hiyerarşik yapı sonucu, grup normlarına biçim veren liderlik, sosyal sermayeyi etkilemektedir.

Bu çalışmada sosyal sermaye, Nahapiet ve Ghoshal (1998)'ın ortaya koyduğu, analiz seviyesi grup ve örgüt düzeyinde olan, sosyal yapı bakış açısıyla oluşturulmuş bilişsel, yapısal ve ilişkisel boyutları çerçevesinde ele alınacaktır. Nahapiet ve Ghoshal (1998)' in bu üç boyutlu sosyal sermaye yapısı literatürde çeşitli araştırmacılar tarafından benimsenmiştir(Andrews, 2010; Bresnen vd., 2003; Chiu vd., 2006; Hau vd., 2013; Inkpen ve Tsang, 2005; Mura vd., 2013). Boyutların arasındaki bağlantıyı anlamak sosyal sermayeyi bir bütün olarak kavramsallaştırabilmek için gereklidir(Lefebvre vd., 2016). Her ne kadar boyutlar birbirleriyle örtüşse de boyutlar ilişkili ve karşılıklı olarak birbirlerini pekiştiren yapılardır. Yapısal boyut, diğer iki boyutun öncülü olarak, ilişki ve yapı bakımından sosyal değişimin gerçekleşebilmesi için gereklidir(Tsai ve Ghoshal, 1998). A $\breve{g}$ bağlantı ilişkileri sosyal etkileşimi gerçekleştirerek bilişsel ve ilişkisel boyutların uyarılmasını sağlar. Yani, sosyal sermayenin bilişsel ve ilişkisel boyutlarının gelişimi ve sürdürebilirliğinin ön şartı sosyal etkileşim olarak yapısal boyuttur. 
Yapısal Boyut: Nahapiet ve Ghoshal (1998) sosyal sermayenin yapısal boyutunu, sosyal sistemin ve bütün olarak ağ bağlantı ilişkileri ile ilgili olduğunu belirtmektedir. Yapısal boyut, bireyi tanıyan ve bireyin yararına olan bilgileri ve yardımı ona sunabilecek ağ bağlantı ilişkileridir. Bu ağ bağlantı ilişkisinde, kişi sayısı ve bu ilişkilerin gücü son derece önemlidir(Davenport ve Daellenbach, 2011). Yapısal boyut, ağ bağlantı süreçlerinin ve örgütün üyelerinin katkısının tanımlanabilmesi gerekli bir unsurdur. Nahapiet ve Ghoshal (1998) yapısal boyutun bilgi paylaşımı ve ilgili faaliyetler ile alakalı olduğunu ileri sürmektedir.

İlişkisel Boyut: İlişkisel boyut insanlığın tarihsel süreçte etkileşimleri sonucu olarak ortaya çıan bir kişisel ilişki türüdür(Nahapiet ve Ghoshal, 1998). İlişkisel boyut güven, yükümlülük ve saygı gibi bireysel ilişkilerin özellikleri ve kalitesi ile ilgilidir(Davenport ve Daellenbach, 2011). Bu boyut birey ve ağ bağlantıda oldukları kişilerin arasında güven/güvenilebilirlik, normlar/yaptırımlar, yükümlülükler/beklentiler ve tanınma/tanımlama ilişkileri ile ilgilidir. İlişkisel boyut sosyal sermayenin, kişilerarası güven, paylaşılan normlar ve diğer bireyler tarafından tanınma olarak duygusal yönünü ortaya koyar(Cabrera ve Cabrera, 2005). Son olarak, Nahapiet ve Ghoshal (1998) ilişkisel boyutun, güven ve güvenilirlik olduğunu belirtmiştir.

Bilişsel Boyut: Sosyal sermayenin bilişsel boyutu, örgütün bireylerinin ortak olarak temsil ettiği, yorumladı̆̆1 değerleri temsil etmektedir(Nahapiet ve Ghoshal, 1998). Bu değerler ortak bir dil ve paylaşılan hikâyelerin bilişsel şeması olarak ortaya çıkmaktadır(Davenport ve Daellenbach, 2011). Bilişsel sosyal sermaye, paylaşılan bir dil ve kod olarak, bireyler arası iletişimin temelidir(Moran, 2005). Nahapiet ve Ghoshal (1998)' a göre bilişsel boyut, ortak algı, beklentiler ve yorumlar çerçevesinde şekillenen örgüt üyelerinin paylaşılan vizyonu ve ortak amaçlarıdır.

Sosyal sermaye, örgütsel alanda mikro ve makro analizlere tabi tutularak, bireysel ve grup/örgüt düzeyinde çıtılara etkisi incelenmiştir. Örneğin mikro düzeyde bireysel çıktı olarak performansa(Seibert vd., 2001), ücretlendirmeye(Seibert vd., 2001), üst yönetime atanmaya(Lester vd., 2008), girişimciliğe(Baron ve Markman, 2003) ve bilgi oluşumuna(McFadyen ve Cannella Jr, 2004) etkileri incelenmiştir. Makro düzeyde gruba ve örgüte etkileri kapsamında, yaratıcıllğa(Perry-Smith ve Shalley, 2003), girişimciliğe(Shane ve Stuart, 2002), performansa(Stam ve Elfring, 2008), finansal kaynaklara ulaşmaya(Gopalakrishnan vd., 2008) ve işletmeler arası rekabete $(\mathrm{Wu}, 2008)$ etkisi araştırılmıştır.

\section{Araştırma Yöntemi Ve Bulgular}

\subsection{Kavramsal Araştırma Modeli ve Hipotezler}

Araştırma kapsamında dönüşümsel liderliğin, sosyal sermayeye etkilerinin ve bu etkide lider-üye etkileşiminin aracılık (mediating) rolünün belirlemek için kurgulanan araştırma modeli Şekil 1'de gösterilmektedir.

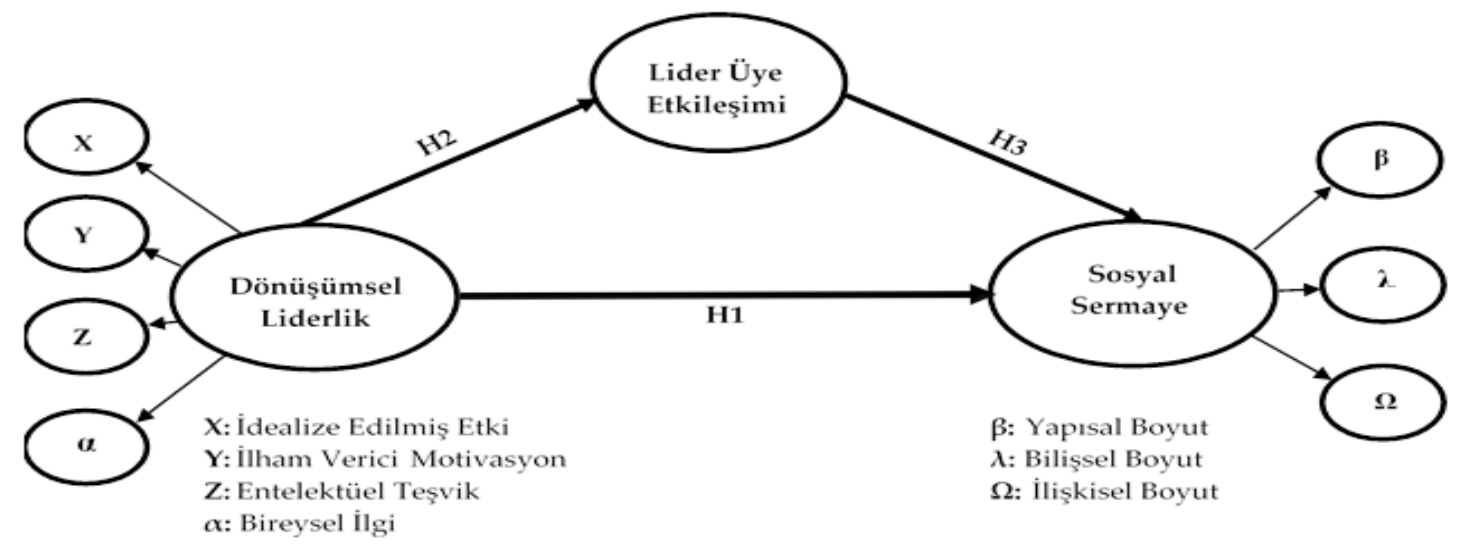

Şekil 1:Araştırma Modeli

Çalışmanın literatürü doğrultusunda oluşturulan araştırma modelini, doğrulamaya çalışacak hipotezler geliştirilerek aşağıda verilmiştir:

$H_{1}$ : Dönüşümsel liderliğin sosyal sermayeye olan etkisi istatistiksel olarak anlamlıdır.

Dönüşümsel liderler takipçileri arasında güven ve işbirliği ortamı oluştururlar(Schaubroeck vd., 2011). Dönüşümsel liderler imrenilen, güvenilen ve saygı duyulan bir rol model olarak, etik ve ahlaki değerler 
çerçevesinde ilham verici idealize edilmiş etki gösteren davranışlar sergilerler(Bono ve Anderson, 2005). Dahası dönüşümsel liderler takipçilerine bireysel ilgi göstererek kendileri ve örgüt için adalet algısı oluşturur(Sosik vd., 2004). Bu alg1 takipçiler arasında güvene dayalı yatay ilişkiler sonucunu beraberinde getirir. Diğer taraftan, dönüşümsel liderler takipçilerine bilgi paylaşımı konusunda ilham verirler(Carmeli vd., 2013). Aynı zamanda entelektüel etkileri ile işbirlikçi norm düzlemi ve açık iletişim sağlayarak takipçiler arasında artan bilgi paylaşımını teşvik ederler(Hempel vd., 2009; Oliver vd., 2011). Dönüşümsel liderler, karizmaları ile tüm örgütsel etki mekanizmalarının merkezi noktasında olarak(Bono ve Anderson, 2005), hedeflerin örgüt çapında yayılmasını, problemlerin öngörülmesini, tavsiyede bulunulmasını ve kaynak akışının yönetilmesini sağlarlar(Sauer ve Kauffeld, 2015). Son olarak dönüşümsel liderler takipçilerin gelecek vizyonlarını örgütün stratejik yönelimleri doğrultusunda şekillendirerek(Bono ve Anderson, 2005; Jansen vd., 2008) kendi çıkarlarının ötesinde örgüt çıkarlarını anlamlandırır, takipçiler arasında ortak bir değere dönüştürür(Podsakoff vd., 1990). Bunun sonucu olarak takipçiler ortak hedeflerin ve vizyonun gerçekleştirilmesi konusunda teşvik edilmiş olur(Gupta vd., 2011).

$\mathrm{H}_{2}$ : Dönüşümsel liderliğin lider-üye etkileşimine etkisi istatistiksel olarak anlamlıdır.

Dönüşümsel liderler bireysel ilgi ile takipçilerine destek oldukça(Zacher vd., 2014), takipçiler aralarındaki değişimin kalitesini yüksek algılarlar(Chun vd., 2016). Bu dönüşümsel liderlik karakterli bireysel ilgi davranışı, lider ve takipçi arasında sosyal değişimin kalitesini artırarak, karşılıklılık normu geliştirir(Cropanzano ve Mitchell, 2005). Aynı zamanda, dönüşümsel liderlik, yüksek kaliteli lider-üye etkileşimi ilişkilerinin geliştirilmesi için elverişli bir ortam yaratarak(Anand vd., 2011), takipçilerin onlara ilham veren ve onları motive eden liderleri olumlu algılamalarını sağlamaktadır(Judge ve Piccolo, 2004). Bu olumlu alg1 ise liderle daha kaliteli ilişkiler geliştirmek için takipçilerin daha fazla çaba saf etmeleri konusunda arzu duymalarını sağlamaktadır(Maslyn ve Uhl-Bien, 2001).

$\mathrm{H}_{3}$ : Lider-üye etkileşiminin sosyal sermayeye olan etkisi istatistiksel olarak anlamlıdır.

Lider-üye etkileşimi sonucu gelişen yüksek kaliteli ilişkilerle, takipçi kendisini örgütsel çevreye kabul ettirerek sosyal sermayesini güçlendirir(Westphal ve Clement, 2008; Westphal ve Stern, 2007). Aynı zamanda Lider-üye etkileşimi sonucu gelişen yüksek kaliteli ilişkiler, takipçinin popülaritesini artırarak sosyal sermayesinin gelişimine katkıda bulunur(Scott, 2013; Scott ve Judge, 2009). Diğer taraftan, yüksek kaliteli lider-üye etkileşimi sosyal ilişkiyi temsil ederek takipçiler arasında güveni sağlar. Aynı zamanda bu lider ve takipçi arasında iki yönlü ilişkiler, daha fazla bilgi paylaşımını sağlayarak vizyon birlikteliği sağlar(Goodwin vd., 2009).

$H_{4}$ :Dönüşümsel liderliğin sosyal sermaye üzerindeki etkisinde lider-üye etkileşiminin aracılık rolü vardır.

Dönüşümsel liderlik, davranış biçimi olarak liderlerin örgüt içerisinde bireylerin davranışları sonucu yakın ve işbirliğine dayalı ilişkiler geliştirmek amacı odaklı, istikrarlı bir sistem geliştirmedir(Adler ve Kwon, 2002; Herman ve Chiu, 2014). Bu noktada, istikrar önemlidir, çünkü sosyal sermaye, zaman içindeki kişiler arası ilişkiler ve paylaşımlar sonucu oluşan iyi niyet birikimini yansıtır. Ayrıca, bu istikrar seviyesi, karşılıklı yükümlülüklerin görünürlüğünü ve bunun yanında güven ve işbirliği normlarının gelişimini ve lider ve takipçi arasında etkili bir iletişimin sonucu olarak artan etkililiğin oluşması ve kazanımlara erişimi sağlar(Gerstner ve Day, 1997). (Coleman, 1988). Ayrıca, grup üyeleri arasında paylaşılan normlar, güven ve özdeşlik hissini kolaylaştıran bir örgütsel iklim yaratır. Daha net ifadelerle, dönüşümsel liderlik teorisi, dönüşümcü liderlerin, takipçilerin kendi öz çıarlarının ötesine geçerek örgüt yararına, takipçiler tarafından paylaşılan ortak bir vizyon geliştirerek, takipçilerin bu vizyona bağlılığını oluşturma ve böylece sosyal sermayenin gelişimine katkıda bulunmalarını etkileyebileceğini savunmaktadır(Bass, 1985).

\subsection{Anakitle Ve Örneklem}

Araştırmanın anakitlesi, Kocaeli Serbest Bölgesi (KSB) çalışanlarıdır. Saha çalışması, anket yöntemi ve yüzyüze görüşme yolu ile yapılmıştır. Daha yüksek temsil düzeyine ulaşabilmek için, örnekleme yöntemi olarak tabakalı örnekleme yöntemi seçilmiştir. Bu bağlamda KSB' de faaliyet gösteren firmaların çalışan sayısı büyüklüğüne göre her bir firma için örneklem sayısı belirlenmiştir. Her bir firma için belirlenen örneklem seçimi ise basit tesadüfi örneklem yöntemi ile yapılmıştır. Bu kapsamda, saha çalışmasının yapıldığı dönemde KSB' de çalışan sayısının taşeron işçi sayısına bağlı olarak 2000 ve 2500 arasında olduğu anakitlede örneklem büyüklüğü \%95 güven aralığında e=\%5 hata payı ile $n=334$ olarak belirlenmiştir. Toplamda 523 kişiye yüzyüze olarak anket uygulanmıştır ve 504 anket formu değerlendirme kapsamına alınmıştır. 


\subsection{Veri Toplama Süreci Ve Kullanılan Ölçekler}

Saha çalışmasıyla veriler, birinci dereceden veri toplamada yaygın olarak kullanılan anket yöntemi kullanılarak elde edilmiştir. Bununla birlikte anketin yüzeysel geçerliliği sağlamak amaciyla saha çalışmasından önce 50 katılımcıyla pilot uygulama yapılmıştır. Anket formu; demografik bilgiler, dönüşümsel liderlik, lider-üye etkileşimi, sosyal sermaye ve özyeterlilik olmak üzere 5 bölümden oluşmaktadır. Anketin ilk bölümünde, belirlenen örneklemin, cinsiyet, yaş, medeni durum ve eğitim durumu gibi demografik ve çalıştıkları işletmenin faaliyet gösterdiği alan ve çalışan sayısı gibi işyeri bilgilerini elde edebilmek amacıyla altı soruya yer verilmiştir.

Dönüşüm liderlik değişkeni için Bass ve Avolio (1991) tarafından geliştirilen çok faktörlü liderlik ölçeği kullanılmıştır. Lider-üye etkileşiminin ölçülmesine yönelik olarak Scandura ve Graen (1984)' in LMX-7 ölçeği kullanılmıştır. Bu çalışmada, sosyal sermaye, Nahapiet ve Ghoshal (1998) tarafından ortaya konulan yapısal, ilişkisel ve bilişsel olmak üzere üç boyutlu bir yapıyla incelenmiştir. Yapısal boyut için, çalışanların arasında bireysel düzeyde bilgi paylaşımı olarak Hyatt ve Ruddy (1997)' nin 6 maddelik etkili iletişim ölçeği kullanılmıştır. İlişkisel boyut için, güven olarak Simons ve Peterson (2000)' in 5 maddelik örgüt içi güven ölçeği kullanılmıştır. Bilişsel boyut ifadeleri toplamda 6 madde olmak üzere ikisi paylaşılan dil kapsamında Tsai ve Ghoshal (1998)'dan adapte edilmiştir. Diğer 4 madde için ise Paylaşılan değer ve hedeflerle ilişkili olarak Gianvito (2007)' nun bilişsel sosyal sermaye ölçeği kullanılmıştır. Anket soruları, 5'li likert tipinde, 'Hiç Katılmıyorum' 'Kesinlikle Katılıyorum' cevaplama aralığında katılımcılara yöneltilmiştir.

\subsection{Verilerin Analizi}

Araştırma kapsamında toplanan verileri ile öncelikle katılımcıların demografik özelliklerini incelemek amacıyla frekans analizi yapılmıştır. Sonrasında, araştırmanın normal dağılıma sahip olup olmadığını belirlemek için basıklık ve çarpıklık katsayıları belirlenmiştir. Bir sonraki aşamada, araştırma kapsamında incelenen ölçeklerin yapısal geçerliliğini tespit etmek amacıyla açımlayıcı faktör analizi yapılmıştır. Araştırmaya konu olan değişkenler, arasında ki ilişkileri belirlemeye yönelik olarak korelasyon analizi uygulanmıştır. Son aşamada ise araştırma modeli çerçevesinde kurgulanan hipotezler basit regresyon ve aracılık etkisinin analizi, Baron ve Kenny (1986)' nin ortaya koyduğu şartlı aşamalar ve Hayes(2013) 'in geliştirdiği process macro yöntemi ile test edilmiştir. Aracılık etkisi, Bootstrap örneklemi 5000 olarak belirlenerek, IBM SPSS 24 paket programının yardımıyla test edilmiştir. İstatistiksel analizlerde \%95 güven aralığı kullanılmıştır.

\subsubsection{Katılımcıların Demografik Özellikleri}

Katılımcıların demografik bilgileri Tablo 12'de verilmiştir. Katılımcıların \% 87,9'u erkek, \% 12,1'i kadındır. Kocaeli Serbest Bölgesinde ki işletmelerin çoğunun gemi inşa sektöründe faaliyet gösteren tersanelerdir. Gemi inşa sektörünün ağır sanayi olması sebebiyle çalışanların çoğunun erkek olması doğaldır. Diğer taraftan, kadın çalışanlar genelde ofis çalışanı olarak istihdam edilmiştir. Yaş dağılımı incelendiğinde, katılımcıların \% 21,2 si 18-29 yaş aralığında, \% 43,7 si 30-39 yaş aralığında, \% 24,2 si 40-49 yaş aralığında ve $\% 10,9^{\prime}$ u 50 ve üzeri yaş aralığındadır. Katılımcıların, işyerlerinin çoğu(\% 79,6) üretim işletmesidir. Bu nedenle işletmeler belirli alanlarda uzmanlıkları olan işgörenleri istihdam etmektedirler. Örneğin, tersane işçileri ağır sanayi olması nedeniyle çalışmaya en erken 18 yaşında başlamaktadırlar. Belirli bir alanda uzmanlaşmaları 10 senelik bir süreci kapsamasından dolayı katılımcıların çoğunun $30-39(\%$ 43,7) yaş aralığında olması normaldir. Katılımcıların \% 21,2' si 18-29 yaş aralığında, \% 24,2' si 40-49 yaş aralığında ve $\%$ 10,9'u 50 üzeri yaşındadır. Katılımcıların \% 74,6' sı evli ve \% 25,4'ü bekârdır. Katılımcıların eğitim düzeyleri incelendiğinde ise \% 66,9' unun İlköğretim ve Lise mezunu, \% 28,1'i lisans mezunu ve \% 5' i lisansüstü mezunudur. Katılımcıların çoğu meslek lisesi mezunu çalışanlardır. Lisans ve lisansüstü mezunu katılımcılar, işletmelerin yöneticileri ve ofis çalışanlarıdır.

\subsubsection{Araştırma Verilerine İlişkin Tanımlayıcı İstatistikler}

Groeneveld ve Meeden (1984)'e göre araştırmada kullanılan verilerin normal dağılım gösterip göstermediğini belirlemek için çarpıklık ve basıklık katsayılarının -1 ile +1 arasında olması gerekmektedir. Tablo 1 incelendiğinde, araştırma kapsamında ele alınan ölçeklere ilişkin veri setinin çarpıklık ve basıklık değerlerinin istenilen sınırlar arasında olduğunu ve bu nedenle verinin normal dağılım özelliğini gösterdiği belirlenmiştir. 
M. Söylemez - M. Tolon 11/1 (2019) 372-389

Tablo 1: Tanımlayıcı İstatistikler

\begin{tabular}{|c|c|c|c|c|c|}
\hline \multicolumn{2}{|r|}{ Ölçekler } & Ortalama & Std. Sapma & Basıklık & Çarpıklık \\
\hline \multirow{4}{*}{ 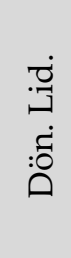 } & İdealize Edilmiş Etki & 3,414 & 0,792 & $-0,258$ & $-0,0453$ \\
\hline & İlham Verici Motivasyon & 3,379 & 0,839 & $-0,165$ & $-0,0451$ \\
\hline & Entelektüel Etki & 3,473 & 0,856 & $-0,115$ & $-0,042$ \\
\hline & Bireysel İlgi & 3,473 & 0,891 & $-0,455$ & $-0,0436$ \\
\hline \multicolumn{2}{|c|}{ Lider-Üye Etkileşimi } & 3,462 & 0,817 & $-0,375$ & $-0,0392$ \\
\hline \multirow{3}{*}{$\begin{array}{l}\dot{\vec{\nu}} \\
\text { के } \\
\text { ळ }\end{array}$} & Yapisal Boyut & 3,554 & 0,784 & $-0,281$ & $-0,0175$ \\
\hline & Bilişsel Boyut & 3,248 & 0,792 & $-0,001$ & $-0,0119$ \\
\hline & İlişkisel Boyut & 3,418 & 0,791 & $-0,411$ & $-0,192$ \\
\hline
\end{tabular}

\subsubsection{Açımlayıcı Faktör Analizi}

Dönüşümsel liderliğin sosyal sermayeye etkisinde lider-üye etkileşiminin aracılık etkisini belirlemek için öncelikle oluşturulan ölçüm aracının yapı geçerliliğini test etmek amacıyla ölçek maddelerine açımlayıcı faktör analizi uygulanmıştır. Çalışmada madde yükleri için belirleyici değer 0,40 olarak belirlenmiştir (Field, 2013). Bu bağlamda, dönüşümsel liderlik ölçeğinin faktör analizine uygunluğu test edilmiştir. KMO değeri 0.947 ve Bartlett test sonucu ki-kare değeri 5442.58 ve $p<0.05$ düzeyinde anlamlı bulunmuştur. Bu sonuçlara göre ölçek faktör analizine uygun bulunmuştur. Faktör analizi yapılmıştır. Dönüşümsel liderlik, dört boyut altında toplanmış ve açıklanan varyansın \% 62,83 olduğu gözlemlenmiştir. Dört boyut altında toplanan dönüşümsel liderlik ölçeğinin Cronbach Alfa değeri hesaplanarak güvenilirlik katsayısının 0,941 olduğu görülerek kabul edilebilir düzey olan 0,70 üzerinde olduğu belirlenmiştir.

Lider-üye etkileşimi ölçeğinin faktör analizine uygunluğu test edilmiştir. KMO değeri 0.901 ve Bartlett test sonucu ki-kare değeri 1496,63 ve p<0.05 düzeyinde anlamlı bulunmuştur. Bu sonuçlara göre ölçek, faktör analizine uygun bulunarak, faktör analizi yapılmıştır. Lider-üye etkileşim ölçeği tek faktörde toplanmış ve varyans açılama yüzdesi \%57.59 olarak gözlenmiştir. Tek boyut altında toplanan lider-üye etkileşim ölçeğinin Cronbach Alfa değeri hesaplanarak güvenilirlik katsayısının 0,876 olduğu görülerek kabul edilebilir düzey olan 0,70 üzerinde olduğu belirlenmiştir.

Sosyal sermaye ölçeği faktör analizine uygunluğu test edilmiş ve KMO değeri 0.921 ve Bartlett test sonucu ki-kare değeri 6613,53 ve p $<0.05$ düzeyinde anlamlı bulunmuştur. Ölçek, üç faktörde toplanmış ve açıklanan varyansın \% 56,22 olduğu gözlemlenmiştir. Üç boyut altında toplanan lider-üye etkileşim ölçeğinin Cronbach Alfa değeri hesaplanarak güvenilirlik katsayısının 0,934 olduğu görülerek kabul edilebilir düzey olan 0,70 üzerinde olduğu belirlenmiştir. Sonuçlara göre, açıklanan varyans oranları \% 50'nin üzerinde ve Barlett küresellik testleri anlamlıdır. Aynı zamanda güvenilirlik katsayıları 0,70'nin üzerindedir. Bu sonuçlar ölçeklerin geçerli ve güvenilir olduğunu göstermektedir.

Ölçeklerin geçerlilik testleri yapıldıktan sonra alt boyut ortalamaları alınarak modelde çoklu doğrusal bağlantı sorunu olup olmadığına bakılmıştır. Bu amaçla çoklu doğrudaşlığa (multicollinearity) bakılmıştır. Tablo 2'de görüleceği üzere elde edilen VIF değerleri bağımsız değişkenler arası çoklu bağlantı olmadığını doğrulayan (VIF<5) sonuçlar vermiştir(Craney ve Surles, 2002; Hair vd., 2006).

Tablo 2: Multicollinearity Tablosu

\begin{tabular}{lcc}
\hline Değişkenler & Tolerans & VIF \\
\hline İdealize Edilmiş Etki & 0,306 & 3,273 \\
İlham Verici Motivasyon & 0,401 & 2,497 \\
Entelektüel Etki & 0,338 & 2,955 \\
Bireysel İlgi & 0,36 & 2,778 \\
Lider-Üye Etkileşimi & 0,271 & 3,696 \\
İlişkisel Boyut & 0,393 & 2,541 \\
Bilişsel Boyut & 0,499 & 2,002 \\
Yapisal Boyut & 0,428 & 2,335 \\
\hline
\end{tabular}




\subsubsection{Korelasyon analizi}

Dönüşümsel liderlik, sosyal sermaye ve lider-üye etkileşimi boyutları arasındaki ilişkinin incelenmesi amacıyla boyutların ölçek puanları arasında korelasyon analizi yapılmıştır. Tablo 3' te belirtilen boyutlar arasındaki korelasyon katsayıları incelendiğinde, dönüşümsel liderlik ve sosyal sermaye arasındaki korelasyon katsayısı 0.563; dönüşümsel liderlik ve lider-üye etkileşimi arasındaki korelasyon katsayısı 0,822; sosyal sermaye ve lider-üye etkileşimi arasındaki korelasyon katsayısı 0,573 olarak ilişkilerin anlamlı olduğu görülmektedir.

Tablo 3: Korelasyon Katsayıları

\begin{tabular}{llccc}
\hline & & Dön.Lid. & Sos.Ser. & Lid. ÜyeEtk. \\
Dön.Lid. & Pearson korelasyonu & - & & \\
Sos. Ser. & Pearson korelasyonu & $0.563^{*}$ & - & \\
Lid. Üye Etk. & Pearson korelasyonu & $0.822^{*}$ & $0.573^{*}$ & - \\
\hline
\end{tabular}

${ }^{*} \mathrm{p}<0.01 ; \mathrm{n}=504$

Boyutlar arasındaki bu yüksek ilişki değerleri teorik olarak literatürdeki bilgileri destekler niteliktedir. Boyutların arasındaki en güçlü ilişki olan; dönüşümsel liderlik ile lider-üye etkileşiminin arasındaki ilişki ve yüksek anlamlılığa sahip diğer ilişkiler, modelin tutarlılığını ortaya koyarak literatür bilgilerini desteklemektedir.

\subsubsection{Regresyon Analizleri ve Lider-Üye Etkileşiminin Aracılık Rolü}

Araştırmada ileri sürülen etki mekanizmalarının varlığı, doğruluğu ve güçleri regresyon analizleri ile incelenmiştir. Ayrıca aracılık etkisinin analizi, Baron ve Kenny (1986)' nin ortaya koyduğu şartlı aşamalar ve Hayes tarafından geliştirilen SPSS macro model 4 ile test edilmiştir(Hayes, 2013). Aracılık etkisi, Bootstrap örneklemi 5000 olarak belirlenerek, IBM SPSS 24 paket programının yardımıyla test edilmiştir.

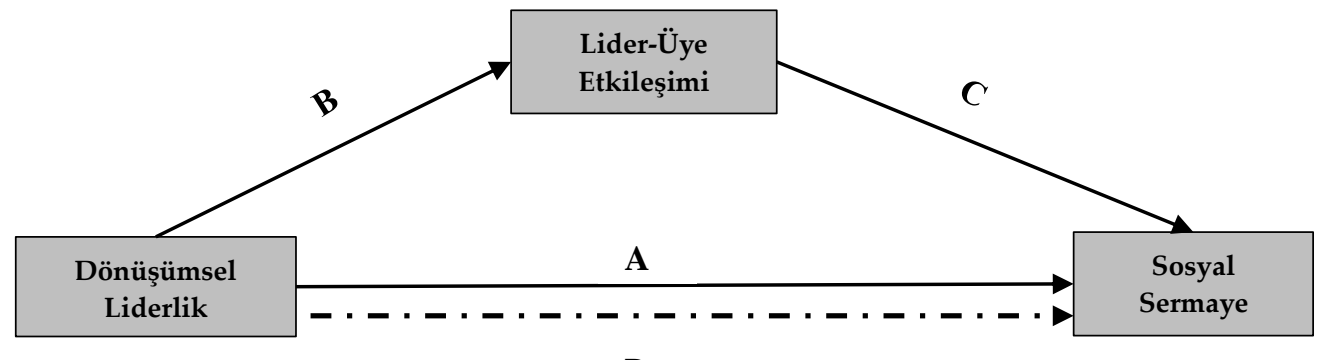

D

Şekil 2:Lider-Üye Etkileşimi Aracılık Modeli

Dönüşümsel liderliğin, sosyal sermaye üzerindeki etkisinde, lider-üye etkileşiminin aracılık rolünü belirlemek amacıyla, şekil 2' de gösterilen model oluşturulmuştur. D harfi ve kesik çizgiler ile simgelendirilen etki, aracı değişken eklenmeden önce dönüşümsel liderliğin, sosyal sermayeye doğrudan etkisini temsil etmektedir. A harfi ile simgelendirilen etki, aracı değişken lider-üye etkileşiminin modele dâhil edilmesiyle dönüşümsel liderliğin, sosyal sermayeye doğrudan etkisini temsil etmektedir. B harfi ile simgelendirilen etki, dönüşümsel liderliğin lider-üye etkileşimine etkisini temsil etmektedir. $C$ harfi ile simgelendirilen etki ise lider-üye etkileşiminin sosyal sermaye üzerindeki etkisini temsil etmektedir.

Tablo 4: Regresyon Analizi Sonuçları

\begin{tabular}{|c|c|c|c|c|c|c|c|}
\hline \multirow[b]{4}{*}{ Sabit } & \multicolumn{7}{|c|}{ B Etkisi(Dönüşümsel Liderliğin Lider-Üye Etkileşimine Etkisi) } \\
\hline & \multicolumn{7}{|c|}{ Lider-Üye Etkileşimi } \\
\hline & $\beta$ & SE & $\mathrm{T}$ & $\mathbf{P}$ & R2 & $\mathbf{F}$ & Sig. \\
\hline & 0,351 & 0,098 & 3,573 & 0,004 & \multirow{2}{*}{0,676} & \multirow{2}{*}{1047,99} & \multirow{2}{*}{0,000} \\
\hline \multirow[t]{4}{*}{ Dön. Liderlik } & 0,906 & 0,028 & 32,372 & 0,000 & & & \\
\hline & \multicolumn{7}{|c|}{ C Etkisi(Lider-Üye Etkileşiminin Sosyal Sermayeye Etkisi) } \\
\hline & \multicolumn{7}{|c|}{ Sosyal sermaye } \\
\hline & $\beta$ & SE & $\mathrm{T}$ & $\mathbf{P}$ & R2 & $\mathbf{F}$ & Sig. \\
\hline Sabit & 1,686 & 15,031 & 12,683 & 0,000 & \multirow[b]{2}{*}{0,329} & \multirow{2}{*}{245,76} & \multirow{2}{*}{0,000} \\
\hline Lid. Üye Etk. & 0,494 & 15,677 & 15,253 & 0,000 & & & \\
\hline
\end{tabular}


M. Söylemez - M. Tolon 11/1 (2019) 372-389

\section{Etkisi(Dönüşümsel Liderliğin Sosyal Sermayeye Etkisi)}

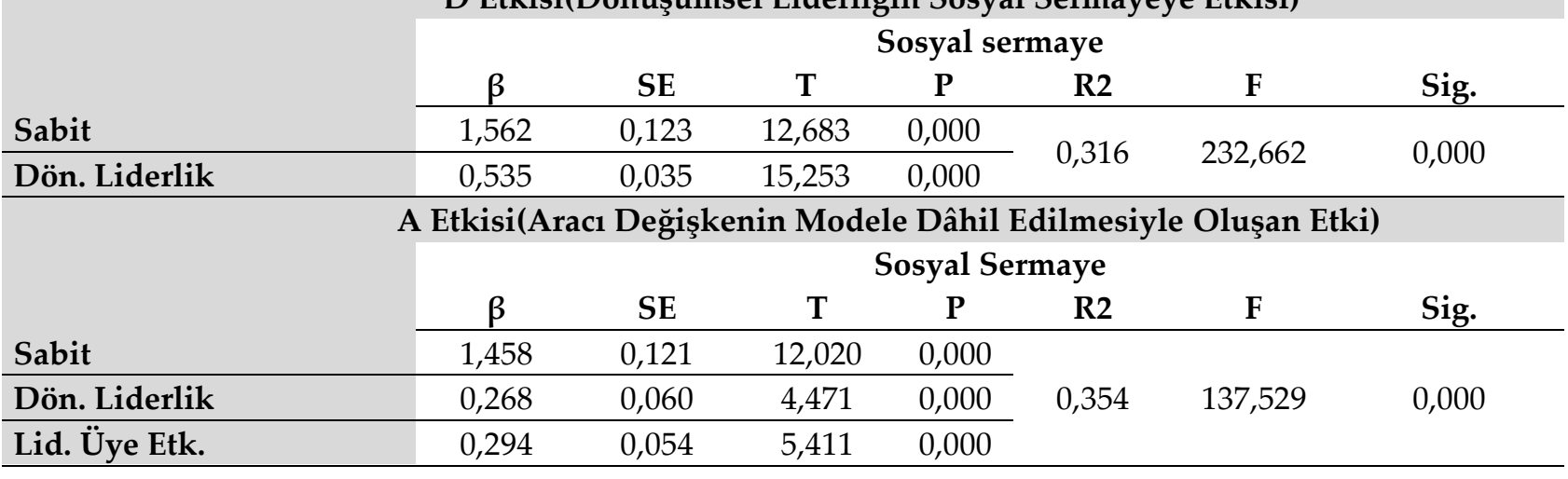

Dönüşümsel liderliğin ve sosyal sermayenin, tüm boyutları dikkate alınarak uygulanan doğrusal regresyon sonuçları, dönüşümsel liderliğin sosyal sermayeyi etkilediğini göstermektedir (sig.=0.000). Model, etki ilişkisini pozitif yönde göstermekte $(\beta=0,535)$ ve model açıklayıcılığı anlamlı bir seviyededir $\left(R^{2}=0.316\right)$. Tablo 4'te belirtilen D etkisinde görüleceği gibi, bu sonuç $H_{1}$ 'i destekleyerek dönüşümsel liderliğin, bilgi paylaşımı, güven, paylaşılan değer ve hedefler üzerindeki etkilerini yansıtarak sosyal sermayeyi etkilediğini göstermektedir.

Dönüşümsel liderliğin tüm boyutları dikkate alınarak uygulanan doğrusal regresyon sonuçları, dönüşümsel liderliğin, lider-üye etkileşimini etkilediğini göstermektedir (sig.=0.000). Model, etki ilişkisini pozitif yönde göstermekte $(\beta=0,906)$ ve model açıklayıcılığı anlamlı ve yüksek bir seviyededir $\left(R^{2}=0.676\right)$. Tablo $4^{\prime}$ te belirtilen $\mathrm{B}$ etkisinde görüleceği gibi bu sonuç $H_{2}$ 'yi destekleyerek, dönüşümsel liderliğin, lider-üye etkileşimine güçlü etkisini ortaya koymuştur.

Sosyal sermayenin tüm boyutları dikkate alınarak uygulanan doğrusal regresyon sonuçları, lider-üye etkileşiminin, sosyal sermayeyi etkilediğini göstermektedir (sig.=0.000). Model, etki ilişkisini pozitif yönde göstermekte $(\beta=0,494)$ ve model açıklayıcılığı anlamlı bir seviyededir $\left(R^{2}=0.329\right)$ Bu sonuç, Tablo $4^{\prime}$ te belirtilen $\mathrm{C}$ etkisinde görüleceği gibi $H_{3}$ 'ü destekleyerek lider-üye etkileşiminin sosyal sermayeyi etkilediğini göstermektedir.

Tablo 5:Aracilık Etkisi

\begin{tabular}{|l|c|c|c|}
\hline & $\begin{array}{c}\text { Doğrudan Etki } \\
\end{array}$ & $\begin{array}{c}\text { Doğrudan Etki } \\
{ }^{1}\end{array}$ & $\begin{array}{c}\text { Dolaylı Etki } \\
\boldsymbol{\beta}\end{array}$ \\
\hline Dön.Lid. - Lid.Üye Etk. - Sos. Ser. & 0,535 & 0,268 & 0,267 \\
\hline
\end{tabular}

${ }^{1}$ Aracı Değişken Eklenmeden Önce; ${ }^{2}$ Aracı Değişken Eklendikten Sonra, BootLLCI: 0,249, BootULCI: 0,516

Dönüşümsel liderliğin, sosyal sermaye etkisinde, lider-üye etkileşiminin aracı değişken olarak modele dahil edilmesiyle, dönüşümsel liderliğin sosyal sermayeye doğrudan etkisi, A etkisi ile Tablo 4'te belirtildiği gibi anlamlıdır $(\beta=0,268)$. Ve açıklayıcılığı anlamlı bir seviyededir $\left(R^{2}=0.354\right)$. Dolaylı etki, Process Macro Versiyon 3 ile 5000 bootstrap tahmin yaklaşımı ile test edilmiştir(Hayes, 2013). Tablo 5'te görülen sonuçlara göre dolaylı etki anlamlı $(\beta=0,267)$ ve doğrudan etkinin yaklaşık olarak $\% 50$ sini açıklamaktadır. Ayrıca CI değerleri 0,249 ve 0,516 aralığında sıfır noktasını içermeyerek \%95 güven aralığında aracılık etkisinin varlığını belirtmektedir. Bu sonuçlar, $H_{4}$ destekleyerek, dönüşümsel liderliğin sosyal sermayeye etkisinde, lider-üye etkileşiminin kısmi aracılık rolü oynadığını göstermektedir.

\section{Sonuç Ve Değerlendirme}

Araştırma sonuçları birkaç önemli bulguyu ortaya koymaktadır. İlk olarak, öngörüldüğü gibi dönüşümsel liderlik, sosyal sermaye ile pozitif olarak ilişkilidir. Ayrıca lider-üye etkileşimi, bu ilişkide aracı rolü oynamaktadır. Bu bulgular örgütlerin rekabet üstü olmasında, kritik bir kaynak olan sosyal sermayenin(Nahapiet ve Ghoshal, 1998), liderlik tarafından nasıl etkilendiğini ortaya koymaktadır. Daha spesifik olarak, artan iş çevresi karmaşıklı̆̆ına bağlı olarak, çalışanların, grup veya örgüt düzeyinde örgütsel amaçlar etrafında birleştirmek çok önemlidir. Bu önemle beraber, her zamankinden daha fazla, örgütsel başarıya ulaşmak için, çalışanlardan, kişisel çıkarlarını feda ederek, ortak örgütsel hedefleri benimsemeleri beklenmektedir. Araştırmacılar, dönüşümsel liderliğin etkisini, bundan önceki çalışmalarda, motivasyon teorisine odaklanarak, liderlik ile farklı davranış çıktıları ve tutumları arasındaki ilişkiyi açıklamaya 
çalışmaktadır (Choi vd., 2016; Hackett vd., 2018; Mason vd., 2014; Muchiri vd., 2012; Wang vd., 2011). Bu çalışma ise, sosyal değişimin, dönüşümsel liderliğin, sosyal sermaye gibi önemli bir örgütsel kaynakları şekillendirmede ki kritik rolüne odaklanmaktadır. Örgütler, grup ve proje tabanlı sistemlere doğru geçiş yapmaya devam ederken, çalışanların arasında ki sosyal değişimin nasıl gerçekleştiği ve sosyal sermaye ile ilgili çalışmalar önemli hale gelmektedir. Aynı zamanda, dönüşümsel liderliğin, sosyal sermaye üzerindeki direkt etkisine ilave olarak, takipçilerin, lider-üye etkileşimini, lider ve takipçiler arasındaki iki yönlü bir sosyal değişim olarak algılamaları, dönüşümsel liderliğin sosyal sermaye üzerindeki etkisini güçlendirmektedir. Bu sonuçlar, bu ilişkiyi, etkileyebilecek daha fazla kavramsal faktörün araştırılmaya olan ihtiyacını vurgulamaktadır. Diğer taraftan liderlik araştırmalarında, sosyal bakış açısı çok önemlidir(Day, 2000). Bu çerçevede bu araştırmanın bulguları, örgütsel çıktıları etkileme mekanizmasında, dönüşümsel liderliğin işlevinin, sosyal değişim bakış açısıyla yorumlanabilmesi için somut veriler sunarak, bundan sonraki çalışmalarda, dönüşümsel liderliğin sosyal sermayenin bir öncülü olarak araştırılması konusunda ilham vermektedir.

Bu çalışma, dönüşümsel liderliğin ilişkisel yönünü vurgulayarak, dönüşümsel liderlerin önemli örgütsel çıtılardan sosyal sermaye ve lider-üye etkileşimi gibi önemli kavramları etkileyen alternatif bir güç olduğunu savunmaktadır. Dönüşümsel liderler takipçileri tarafından güvenilir ve destekleyici olarak algılanır. Bu algı takipçilerin örgüte daha iyi uyum sağlamalarını sağlayan psikolojik rahatlık ve güvenlik duygusunu verir. Benzer şekilde, liderin vizyonunu paylaşarak, diğer takipçiler ile birlikte uyumlu bir sosyal varlık haline gelerek, lider tarafından belirlenen ortak amaçlara ulaşmak için işbirliği içinde çalışır. Bu uyum ve paylaşılan liderlik etrafında işbirliği içinde çalışma, bilgi gibi olumlu sosyal değişimlerle sonuçlanarak, örgütte güçlü bir sosyal sermaye yapısına yol açar.

Dönüşümsel liderliğin sosyal sermayeyi etkilemesinde, lider-üye etkileşimin aracılık rolü oynaması ile ilgili bulgular Graen ve Uhl-Bien (1995)' in ilişki tabanlı liderlik gözlemini, sosyal değişim çerçevesinde genişletmeyi amaçlamaktadır. Dönüşümsel liderler, takipçilerine gösterdikleri bireysel ilgi ile takipçilerine destek olur. Bu destek, takipçiler ve liderle arasındaki sosyal değişimin kalitesini yükselterek, takipçinin karşılıklılık normu geliştirmesini sağlar. Takipçide oluşan bu olumlu algı ise, liderle daha kaliteli ilişkiler geliştirmek için takipçinin daha fazla çaba saf etmesini ve artan lider-üye etkileşimi sağlar. Diğer takipçilerle, iş birliği içinde liderin vizyonu etrafında, örgütsel amaçlara ulaşmada, lider ve üye arasında gelişen bu iki yönlü kaliteli ilişkiler, takipçilerin kendilerini, örgütsel çevreye kabul ettirerek, sosyal sermayesini güçlendirir. Diğer taraftan, yüksek kaliteli lider-üye etkileşimi, sosyal ilişkiyi temsil ederek takipçiler arasında güveni sağlar. Aynı zamanda bu lider ve takipçi arasında iki yönlü sosyal değişime dayanan ilişkiler, daha fazla bilgi paylaşımını sağlayarak örgütsel amcalara ulaşmayı kolaylaştırır.

Gelecekte dönüşümsel liderliğin sosyal sermayeye etkisine yönelik yapılacak araştırmalarda, örgütlerin amaçlarına ulaşmasını kolaylaştıran, sosyal değişim ile ilgili daha fazla kavramsal faktöre odaklanmalıdır. Bu çalışmaya benzer şekilde, dönüşümsel liderliğin sosyal sermaye etkisi, örgütsel adalet(Konovsky, 2000), psikolojik sözleşme(Rousseau, 1998) ve kişi örgüt uyumu(Kristof, 1996) gibi değişkenlerin aracılık etkisinde incelenmelidir. Aynı zamanda hizmetkâr liderlik(Greenleaf, 1997) gibi diğer liderlik paradigmalarının, sosyal sermaye etkisini incelemek, araştırmacılar için ilginç bir başlangıç noktası olabilecektir.

\section{Kaynakça}

Adler, P. S., ve Kwon, S.-W. (2002). Social capital: Prospects for a new concept. Academy of management review, $27(1), 17-40$.

Akram, T., Lei, S., Hussain, S. T., Haider, M. J., ve Akram, M. W. (2016). Does relational leadership generate organizational social capital? A case of exploring the effect of relational leadership on organizational social capital in China. Future Business Journal, 2(2), 116-126.

Anand, S., Hu, J., Liden, R. C., ve Vidyarthi, P. R. (2011). Leader-member exchange: Recent research findings and prospects for the future. In D. C. A. Bryman, B. J. K. Grint, ve M. Uhl-Bien (Eds.), The Sage handbook of leadership (pp. 311-325). Thousand Oaks: Sage Books.

Hayes, Andrew F. (2013). Introduction to Mediation, Moderation, and Conditional Process Analysis: A Regression-Based Approach. New York, NY: The Guilford Press

Andrews, R. (2010). Organizational social capital, structure and performance. Human relations, 63(5), 583-608. 
M. Söylemez - M. Tolon 11/1 (2019) 372-389

Avolio, B. J., ve Bass, B. (1993). Transformational leadership: a response to critiques. In M. Chemers ve R. Ayman (Eds.), Leadership Theory Research. : San Diego, CA: Academic Press.

Avolio, B. J., Bass, B. M., ve Jung, D. I. (1999). Re-examining the components of transformational and transactional leadership using the Multifactor Leadership. Journal of occupational organizational psychology, 72(4), 441-462.

Avolio, B. J., Zhu, W., Koh, W., ve Bhatia, P. (2004). Transformational leadership and organizational commitment: Mediating role of psychological empowerment and moderating role of structural distance. Journal of Organizational Behavior: The International Journal of Industrial, Occupational Organizational Psychology Behavior, 25(8), 951-968.

Balkundi, P., ve Kilduff, M. (2006). The ties that lead: A social network approach to leadership. The leadership quarterly, 17(4), 419-439.

Banks, G. C., McCauley, K. D., Gardner, W. L., ve Guler, C. E. (2016). A meta-analytic review of authentic and transformational leadership: A test for redundancy. The leadership quarterly, 27(4), 634-652.

Baron, R. A., ve Markman, G. D. (2003). Beyond social capital: The role of entrepreneurs' social competence in their financial success. Journal of business venturing, 18(1), 41-60.

Baron, R. M., ve Kenny, D. A. (1986). The moderator-mediator variable distinction in social psychological research: Conceptual, strategic, and statistical considerations. Journal of personality social psychology, 51(6), 1173.

Bass, B. M. (1985). Leadership and performance beyond expectations: Collier Macmillan.

Bass, B. M. (1990). From transactional to transformational leadership: Learning to share the vision. Organizational Dynamics, 18(3), 19-31.

Bass, B. M., ve Avolio, B. J. (1991). The Multifactor Leadership Questionnaire: Form 5x. Center for Leadership Studies, State University of New York, Binhampton, NY.

Bass, B. M., ve Riggio, R. E. (2006). Transformational leadership. London: Lawrence Erlbaum Associates.

Bhandari, H., ve Yasunobu, K. (2009). What is social capital? A comprehensive review of the concept. Asian Journal of Social Science, 37(3), 480-510.

Biddle, B. J. (1986). Recent developments in role theory. Annual review of sociology, 12(1), 67-92.

Blau, P. M. (1964). Exchange and Power in Social Life: Transaction Publishers.

Bolino, M. C., Turnley, W. H., ve Bloodgood, J. M. (2002). Citizenship behavior and the creation of social capital in organizations. Academy of management review, 27(4), 505-522.

Bono, J. E., ve Anderson, M. H. (2005). The advice and influence networks of transformational leaders. Journal of Applied Psychology, 90(6), 1306.

Bourdieu, P. (1986). The forms of capital In J. G. Richardson (Ed.), Handbook of theory and research for the sociology of education (pp. 241-258). New York. : Greenwood Press.

Boxall, P. (1996). The strategic HRM debate and the resource-based view of the firm. Human Resource Management Journal, 6(3), 59-75.

Bresnen, M., Edelman, L., Newell, S., Scarbrough, H., ve Swan, J. (2003). Social practices and the management of knowledge in project environments. International journal of project management, 21(3), 157-166.

Brown, M. E., ve Treviño, L. K. (2006). Ethical leadership: A review and future directions. The leadership quarterly, 17(6), 595-616.

Burt, R. S. (1997). The contingent value of social capital. Administrative science quarterly, 339-365.

Cabrera, E. F., ve Cabrera, A. (2005). Fostering knowledge sharing through people management practices. The International Journal of Human Resource Management, 16(5), 720-735.

Carmeli, A., Gelbard, R., ve Reiter-Palmon, R. (2013). Leadership, creative problem?solving capacity, and creative performance: The importance of knowledge sharing. Human Resource Management Journal, 52(1), 95-121.

Chiu, C.-M., Hsu, M.-H., ve Wang, E. T. (2006). Understanding knowledge sharing in virtual communities: An integration of social capital and social cognitive theories. Decision support systems, 42(3), 1872-1888. 
M. Söylemez - M. Tolon 11/1 (2019) 372-389

Choi, S. L., Goh, C. F., Adam, M. B. H., ve Tan, O. K. (2016). Transformational leadership, empowerment, and job satisfaction: the mediating role of employee empowerment. Human resources for health, 14(1), 73.

Chun, J. U., Cho, K., ve Sosik, J. J. (2016). A multilevel study of group-focused and individual-focused transformational leadership, social exchange relationships, and performance in teams. Journal of Organizational Behavior, 37(3), 374-396.

Coleman, J. S. (1988). Social capital in the creation of human capital. American journal of sociology, 94, 95-S120.

Craney, T. A., ve Surles, J. G. (2002). Model-dependent variance inflation factor cutoff values. Quality Engineering, 14(3), 391-403.

Cropanzano, R., ve Mitchell, M. S. (2005). Social exchange theory: An interdisciplinary review. Journal of Management Studies, 31(6), 874-900.

Davenport, S., ve Daellenbach, U. (2011). 'Belonging'to a virtual research centre: exploring the influence of social capital formation processes on member identification in a virtual organization. British Journal of Management, 22(1), 54-76.

Day, D. V. (2000). Leadership development:: A review in context. The leadership quarterly, 11(4), 581-613.

Erdogan, B., Kraimer, M. L., ve Liden, R. C. (2004). Work value congruence and intrinsic career success: The compensatory roles of leader-member exchange and perceived organizational support. Personnel psychology, 57(2), 305-332.

Field, A.(2013).Discovering statistics using IBM SPSS statistics, Sage, Londra

Flap, H. (1995). No Man is an Island. The Research Program of a Social Capital Theory. Paper pres. Paper presented at the Workshop on Rational Choice and Social Networks.

Gerstner, C. R., ve Day, D. V. (1997). Meta-Analytic review of leader-member exchange theory: Correlates and construct issues. Journal of applied psychology, 82(6), 827.

Gianvito, M. A. (2007). Delineating the effects of adjustment and social capital on workplace outcomes. University of Akron,

Goodwin, V. L., Bowler, W. M., ve Whittington, J. L. (2009). A social network perspective on LMX relationships: Accounting for the instrumental value of leader and follower networks. Journal of management, 35(4), 954980 .

Gopalakrishnan, S., Scillitoe, J. L., ve Santoro, M. D. (2008). Tapping deep pockets: the role of resources and social capital on financial capital acquisition by biotechnology firms in biotech-pharma alliances. Journal of Management Studies, 45(8), 1354-1376.

Gouldner, A. W. (1960). The norm of reciprocity: A preliminary statement. American Sociological Review, 25 , 161-178.

Graen, G., Novak, M. A., ve Sommerkamp, P. (1982). The effects of leader-member exchange and job design on productivity and satisfaction: Testing a dual attachment model. Organizational Behavior Human Performance, 30(1), 109-131.

Graen, G. B., ve Scandura, T. A. (1987). Toward a psychology of dyadic organizing. Research in organizational behavior.

Graen, G. B., ve Uhl-Bien, M. (1991). The Transformation of Professionals into Self-Managing and Partially SelfDesigning Contributors: Toward a Theory of Leadership-Making. Journal of Management Systems, 3(3), 49-54.

Graen, G. B., ve Uhl-Bien, M. (1995). Relationship-based approach to leadership: Development of leader-member exchange (LMX) theory of leadership over 25 years: Applying a multi-level multi-domain perspective. The leadership quarterly, 6(2), 219-247.

Grant, R. M. (1991). The resource-based theory of competitive advantage: implications for strategy formulation. California management review, 33(3), 114-135.

Greenleaf, R. K. (1997). The servant as leader: University of Notre Dame Press.

Groeneveld, R. A. and Meeden, G. (1984), "Measuring Skewness and Kurtosis," Journal of the Royal Statistical Society. Series D (The Statistician), 33, 391-399 
Gupta, V. K., Huang, R., ve Yayla, A. A. (2011). Social capital, collective transformational leadership, and performance: A resource-based view of self-managed teams. Journal of managerial issues, 31-45.

Hackett, R. D., Wang, A. C., Chen, Z., Cheng, B. S., ve Farh, J. L. (2018). Transformational Leadership and Organisational Citizenship Behaviour: A Moderated Mediation Model of Leader-Member-Exchange and Subordinates' Gender. Applied Psychology, 67(4), 617-644.

Hair, J. F., Black, W. C., Babin, B. J., Anderson, R. E., ve Tatham, R. L. (2006). Multivariate data analysis (Vol. 6): Upper Saddle River, NJ: Pearson Prentice Hall.

Harris, T. B., Li, N., ve Kirkman, B. L. (2014). Leader-member exchange (LMX) in context: How LMX differentiation and $L M X$ relational separation attenuate $L M X^{\prime}$ 's influence on OCB and turnover intention. The leadership quarterly, 25(2), 314-328.

Hau, Y. S., Kim, B., Lee, H., ve Kim, Y.-G. J. I. J. o. I. M. (2013). The effects of individual motivations and social capital on employees' tacit and explicit knowledge sharing intentions. 33(2), 356-366.

Hempel, P. S., Zhang, Z. X., ve Tjosvold, D. B. (2009). Conflict management between and within teams for trusting relationships and performance in China. Journal of Organizational Behavior: The International Journal of Industrial, Occupational Organizational Psychology, 30(1), 41-65.

Henderson, D. J., Wayne, S. J., Shore, L. M., Bommer, W. H., ve Tetrick, L. E. (2008). Leader--member exchange, differentiation, and psychological contract fulfillment: A multilevel examination. Journal of applied psychology, 93(6), 1208.

Herman, H., ve Chiu, W. C. (2014). Transformational leadership and job performance: A social identity perspective. Journal of Business Research, 67(1), 2827-2835.

Hitt, M. A., Lee, H.-U., ve Yucel, E. (2002). The importance of social capital to the management of multinational enterprises: Relational networks among Asian and Western firms. Asia Pacific Journal of Management, 19(2-3), 353-372.

Hodson, R. (2005). Management behaviour as social capital: A systematic analysis of organizational ethnographies. British Journal of Industrial Relations, 43(1), 41-65.

Huber, F. (2009). Social capital of economic clusters: Towards a network-based conception of social resources. Tijdschrift voor economische en sociale geografie, 100(2), 160-170.

Huselid, M. A. (1995). The impact of human resource management practices on turnover, productivity, and corporate financial performance. Academy of Management Journal, 38(3), 635-672.

Hyatt, D. E., ve Ruddy, T. M. (1997). An examination of the relationship between work group characteristics and performance: Once more into the breech. Personnel psychology, 50(3), 553-585.

Ibarra, H., Kilduff, M., ve Tsai, W. (2005). Zooming in and out: Connecting individuals and collectivities at the frontiers of organizational network research. Organization science, 16(4), 359-371.

Inkpen, A. C., ve Tsang, E. W. (2005). Social capital, networks, and knowledge transfer. Academy of management review, 30(1), 146-165.

Jansen, J. J., George, G., Van den Bosch, F. A., ve Volberda, H. W. (2008). Senior team attributes and organizational ambidexterity: The moderating role of transformational leadership. Journal of Management Studies, 45(5), 982-1007.

Johnson, S. G., Schnatterly, K., ve Hill, A. D. (2013). Board composition beyond independence: Social capital, human capital, and demographics. Journal of management, 39(1), 232-262.

Judge, T. A., ve Bono, J. E. (2000). Five-factor model of personality and transformational leadership. Journal of applied psychology, 85(5), 751.

Judge, T. A., Bono, J. E., Ilies, R., ve Gerhardt, M. W. (2002). Personality and leadership: a qualitative and quantitative review. Journal of applied psychology, 87(4), 765.

Judge, T. A., ve Piccolo, R. F. (2004). Transformational and transactional leadership: a meta-analytic test of their relative validity. Journal of applied psychology, 89(5), 755.

Katz, D., ve Kahn, R. L. (1978). The social psychology of organizations (Vol. 2): Wiley New York.

Kaufman, B. E. (2015). The RBV theory foundation of strategic HRM: critical flaws, problems for research and practice, and an alternative economics paradigm. Human Resource Management Journal, 25(4), 516-540. 
Konovsky, M. A. (2000). Understanding procedural justice and its impact on business organizations. Journal of management, 26(3), 489-511.

Kristof, A. L. (1996). Person-organization fit: An integrative review of its conceptualizations, measurement, and implications. Personnel psychology, 49(1), 1-49.

Lefebvre, V. M., Sorenson, D., Henchion, M., ve Gellynck, X. (2016). Social capital and knowledge sharing performance of learning networks. International Journal of Information Management, 36(4), 570-579.

Lester, R. H., Hillman, A., Zardkoohi, A., ve Cannella Jr, A. A. (2008). Former government officials as outside directors: The role of human and social capital. Academy of Management Journal, 51(5), 999-1013.

Li, Y., Chen, H., Liu, Y., ve Peng, M. W. (2014). Managerial ties, organizational learning, and opportunity capture: A social capital perspective. Asia Pacific Journal of Management, 31(1), 271-291.

Liao, H., Liu, D., ve Loi, R. (2010). Looking at both sides of the social exchange coin: A social cognitive perspective on the joint effects of relationship quality and differentiation on creativity. Academy of Management Journal, 53(5), 1090-1109.

Liden, R. C., Sparrowe, R. T., ve Wayne, S. J. (1997). Leader-member exchange theory: The past and potential for the future. Research in personnel human resources management, 15, 47-120.

Lin. (1982). Social resources and instrumental action. In P. V. Marsden ve N. Lin (Eds.), Social Structure and Network Analysis (pp. 131-145): State University of New York, Department of Sociology.

Lin, N. (2002). Social capital: A theory of social structure and action (Vol. 19): Cambridge university press.

Liu, J., Siu, O. L., ve Shi, K. (2010). Transformational leadership and employee well-being: The mediating role of trust in the leader and self-efficacy. Applied Psychology, 59(3), 454-479.

Maslyn, J. M., ve Uhl-Bien, M. (2001). Leader-member exchange and its dimensions: Effects of self-effort and other's effort on relationship quality. Journal of applied psychology, 86(4), 697.

Mason, C., Griffin, M., ve Parker, S. (2014). Transformational leadership development: Connecting psychological and behavioral change. Leadership Organization Development Journal, 35(3), 174-194.

McCallum, S., ve O'Connell, D. (2009). Social capital and leadership development: Building stronger leadership through enhanced relational skills. Leadership Organization Development Journal, 30(2), 152-166.

McFadyen, M. A., ve Cannella Jr, A. A. (2004). Social capital and knowledge creation: Diminishing returns of the number and strength of exchange relationships. Academy of Management Journal, 47(5), 735-746.

Molm, L. D. (1994). Dependence and risk: Transforming the structure of social exchange. Social Psychology Quarterly, 57, 163-176.

Moran, P. (2005). Structural vs. relational embeddedness: Social capital and managerial performance. Strategic management journal, 26(12), 1129-1151.

Muchiri, M. K., Cooksey, R. W., ve Walumbwa, F. O. (2012). Transformational and social processes of leadership as predictors of organisational outcomes. Leadership Organization Development Journal, 33(7), 662-683.

Mura, M., Lettieri, E., Radaelli, G., ve Spiller, N. (2013). Promoting professionals' innovative behaviour through knowledge sharing: the moderating role of social capital. Journal of Knowledge Management, 17(4), 527544.

Nahapiet, J., ve Ghoshal, S. (1998). Social capital, intellectual capital, and the organizational advantage. Academy of management review, 23(2), 242-266.

Northouse, P. G. (2018). Leadership: Theory and practice: Sage publications.

Oh, H., Chung, M.-H., ve Labianca, G. (2004). Group social capital and group effectiveness: The role of informal socializing ties. Academy of Management Journal, 47(6), 860-875.

Oliver, P. H., Gottfried, A. W., Guerin, D. W., Gottfried, A. E., Reichard, R. J., ve Riggio, R. E. (2011). Adolescent family environmental antecedents to transformational leadership potential: A longitudinal mediational analysis. The Leadership Quarterly, 22(3), 535-544.

Paldam, M. (2000). Social capital: one or many? Definition and measurement. Journal of economic surveys, 14(5), 629-653. 
M. Söylemez - M. Tolon 11/1 (2019) 372-389

Perry-Smith, J. E., ve Shalley, C. E. (2003). The social side of creativity: A static and dynamic social network perspective. Academy of management review, 28(1), 89-106.

Phelps, C., Heidl, R., ve Wadhwa, A. (2012). Knowledge, networks, and knowledge networks: A review and research agenda. Journal of management, 38(4), 1115-1166.

Piccolo, R. F., ve Colquitt, J. A. (2006). Transformational leadership and job behaviors: The mediating role of core job characteristics. Academy of Management journal, 49(2), 327-340.

Ployhart, R. E. (2006). Staffing in the 21st century: New challenges and strategic opportunities. Journal of management, 32(6), 868-897.

Podsakoff, P. M., MacKenzie, S. B., Moorman, R. H., ve Fetter, R. (1990). Transformational leader behaviors and their effects on followers' trust in leader, satisfaction, and organizational citizenship behaviors. The leadership quarterly, 1(2), 107-142.

Rousseau, D. M. (1998). The 'problem'of the psychological contract considered. Journal of Organizational Behavior: The International Journal of Industrial, Occupational Organizational Psychology Behavior, 19(S1), 665-671.

Sauer, N. C., ve Kauffeld, S. (2015). The ties of meeting leaders: A social network analysis. Psychology, 6(04), 415.

Scandura, T. A., ve Graen, G. B. (1984). Moderating effects of initial leader-member exchange status on the effects of a leadership intervention. Journal of applied psychology, 69(3), 428.

Schaubroeck, J., Lam, S. S., ve Peng, A. C. (2011). Cognition-based and affect-based trust as mediators of leader behavior influences on team performance. Journal of applied psychology, 96(4), 863.

Scott, B. A. (2013). A conceptual framework for the study of popularity in the workplace. Organizational Psychology Review, 3(2), 161-186.

Scott, B. A., ve Judge, T. A. (2009). The popularity contest at work: Who wins, why, and what do they receive? Journal of applied psychology, 94(1), 20.

Seibert, S. E., Kraimer, M. L., ve Liden, R. C. (2001). A social capital theory of career success. Academy of Management Journal, 44(2), 219-237.

Shamir, B., House, R. J., ve Arthur, M. B. (1993). The motivational effects of charismatic leadership: A self-concept based theory. Organization science, 4(4), 577-594.

Shane, S., ve Stuart, T. (2002). Organizational endowments and the performance of university start-ups. Management science, 48(1), 154-170.

Simons, T. L., ve Peterson, R. S. (2000). Task conflict and relationship conflict in top management teams: The pivotal role of intragroup trust. Journal of applied psychology, 85(1), 102.

Sirmon, D. G., Hitt, M. A., ve Ireland, R. D. (2007). Managing firm resources in dynamic environments to create value: Looking inside the black box. Academy of management review, 32(1), 273-292.

Sosik, J. J., Godshalk, V. M., ve Yammarino, F. J. (2004). Transformational leadership, learning goal orientation, and expectations for career success in mentor-protégé relationships: A multiple levels of analysis perspective. The leadership quarterly, 15(2), 241-261.

Sparrowe, R. T., ve Liden, R. C. (1997). Process and structure in leader-member exchange. Academy of management review, 22(2), 522-552.

Stam, W., ve Elfring, T. (2008). Entrepreneurial orientation and new venture performance: The moderating role of intra-and extraindustry social capital. Academy of Management Journal, 51(1), 97-111.

To, M. L., Herman, H., ve Ashkanasy, N. M. (2015). A multilevel model of transformational leadership, affect, and creative process behavior in work teams. The leadership quarterly, 26(4), 543-556.

Tsai, W., ve Ghoshal, S. (1998). Social capital and value creation: The role of intrafirm networks. Academy of Management Journal, 41(4), 464-476.

Tsui, A. S. (1984). A role set analysis of managerial reputation. Organizational Behavior Human Performance, 34(1), 64-96.

Uhl-Bien, M., Graen, G. B., ve Scandura, T. A. (2000). Implications of leader-member exchange (LMX) for strategic human resource management systems: Relationships as social capital for competitive advantage. Research in personnel human resources management, 18, 137-186. 
Van Knippenberg, D., ve Sitkin, S. B. (2013). A critical assessment of charismatic-transformational leadership research: Back to the drawing board? The Academy of Management Annals, 7(1), 1-60.

Wang, G., Oh, I.-S., Courtright, S. H., ve Colbert, A. E. (2011). Transformational leadership and performance across criteria and levels: A meta-analytic review of 25 years of research. Group organization management, $36(2), 223-270$.

Westphal, J. D., ve Clement, M. B. (2008). Sociopolitical Dynamics In Relations Between Top Managers and Security Analysts: Favor Rendering, Reciprocity, and Analyst Stock Recommendations. Academy of Management Journal, 51(5), 873-897. doi:10.5465/amj.2008.34789647

Westphal, J. D., ve Stern, I. (2007). Flattery Will Get You Everywhere (Especially If You Are A Male Caucasian): How Ingratiation, Boardroom Behavior, And Demographic Minority Status Affect Additional Board Appointments at U.S. Companies. Academy of Management Journal, 50(2), 267-288. doi:10.5465/amj.2007.24634434

Whipple, J. M., Wiedmer, R., ve K. Boyer, K. (2015). A dyadic investigation of collaborative competence, social capital, and performance in buyer-supplier relationships. Journal of Supply Chain Management, 51(2), 321.

Wright, P. M., ve McMahan, G. C. (2011). Exploring human capital: putting 'human'back into strategic human resource management. Human Resource Management Journal, 21(2), 93-104.

$\mathrm{Wu}, \mathrm{W}$. p. (2008). Dimensions of social capital and firm competitiveness improvement: The mediating role of information sharing. Journal of Management Studies, 45(1), 122-146.

Youndt, M. A., Snell, S. A., Dean Jr, J. W., ve Lepak, D. P. (1996). Human resource management, manufacturing strategy, and firm performance. Academy of Management Journal, 39(4), 836-866.

Zacher, H., Pearce, L. K., Rooney, D., ve McKenna, B. (2014). Leaders' personal wisdom and leader-member exchange quality: The role of individualized consideration. Journal of Business Ethics, 121(2), 171-187.

Zahra, S. A. (2010). Harvesting family firms' organizational social capital: A relational perspective. Journal of Management Studies, 47(2), 345-366.

Zhu, W., Chew, I. K., ve Spangler, W. D. (2005). CEO transformational leadership and organizational outcomes: The mediating role of human-capital-enhancing human resource management. The leadership quarterly, 16(1), 39-52. 